1 Potential Pharmacodynamic Mechanism of the Main ingredients in

\title{
2 Licorice for Chronic Obstructive Pulmonary Disease
}

3 Cai Chen ${ }^{1 \&}$, Jianpeng $\mathrm{An}^{2 \&}$, Guodong Shen ${ }^{1}$, Yang Shen ${ }^{3 \#}$

$4{ }^{1}$ Shandong Institute of Advanced Technology Chinese Academy of Sciences, Jinan, 250000,

5 China.

6 '2Integrated Traditional Chinese and Western Medicine Hospitial of Tongzhou District, Beijing,

7 China

$8{ }^{3}$ Ministry of Environmental Protection, School of Public Health, Tongji Medical College,

9 Huazhong University of Science and Technology, \#13 Hangkong Road, Wuhan, 430030,

10 Hubei, China

11

$12 \&$ These authors contributed equally to this work.

$13 *$ Corresponding author: YangShen

14 Ministry of Environmental Protection, School of Public Health, Tongji Medical College,

15 Huazhong University of Science and Technology, \#13 Hangkong Road, Wuhan, 430030,

16 Hubei, China. 


\section{Abstract}

Purpose: This study aimed to investigate the effect of essential ingredients of licorice on the chronic obstructive pulmonary disease (COPD). Method: The ingredients information were obtained from PubChem (https://pubchem.ncbi.nlm.nih.gov/), related genes about COPD was collected from geneCards (http://www.genecards.org/).Network pharmacology was utilized in this study. Result: The intersection data set contains 20 molecular targets between COPD and liquorice. Protein-protein interaction network showed that there are a total of 58 nodes and 137 edges involved. The link number of AKT1 in PPI network was 39, which is the highest level of interaction. MAPK1 is an important target of Licorice on COPD. Conclusion: MAPK signaling pathway could be the important key target of main ingredients of licorice on COPD.

Keyword: COPD, licorice, Gene Ontology, Kyoto Encyclopedia of Genes and Genomes, network pharmacology 


\section{Introduction}

Chronic obstructive pulmonary disease (COPD) is one of the common preventable and treatable disease, with the emblematic symptom of persistent airflow restriction, which is associated with an increased chronic inflammatory response of the airways and lungs to toxic particles or gases[1-4]. According to the World Health Organization, approximately 3 million people in the world dead as a consequence of COPD each year. One meta-analysis of global prevalence of COPD, which purposed to examine the global prevalence of COPD in men and women, revealed that prevalence rate of COPD was 9.23\% (95\% CI:8.16\%-10.36\%) among male group and 6.16\% (95\% CI:5.41\%-6.95\%) among female group[5]. Moreover, there were some complications of COPD, such as cardiovascular disease, anxiety and depression, lung cancer [6-8], which leads to the lower living quality and much more burden of patient's life [9, 10].

Liquorice, widely distributed among Asia, Europe, America, etc., has been used as medicinal material for long years[11-13]. Some researches have proved that liquorice has the function of anti-inflammation, preventing coughing, antianaphylaxis and so on $[14,15]$. It was reported that the essential ingredients of liquorice are glycyrrhizic acid, glycyrrhizin, quercetin, and formononetin[16, 17]. Generally, liquorice, the whole plant is utilized to made as pills or decoction. Consequently, the mechanism and molecular pathways for every component was not clear. Up to now, much researches concentrated on the biological effect of liquorice as a whole, while the molecular effect of its every component hasn't been figured out. Considering its bargain price, widespread distribution and unique biological effect, this research purposed to investigate the mechanism of essential component's signaling pathways (formononetin, liquiritin, glycyrrhizic acid, glabridin, quercetin and isoliquiritigenin) based on network pharmacology. 


\section{Method and Materials}

The ingredients of liquorice involved in this research were formononetin, liquiritin, glycyrrhizic acid, glabridin, quercetin and isoliquiritigenin, respectively. Their two-demension and three-demension struction were from public database, PubChem (https://pubchem.ncbi.nlm.nih.gov/). Pharmacokinetic information of these compound was obtained from Traditional Chinese Medicine Systems Pharmacology (TCMSP), including drug-likeness (DL), oral bioavailability (OB), intestinal epithelial permeability (Caco-2) and number of H-bond donor/acceptor (Hdon/Hacc).

The target molecule of the Liquorice ingredients were attained from public database Swisstargetprediction (http://www.swisstargetprediction.ch/). The potential molecular target was selected when the probability was above zero. The related genes about COPD was collected from geneCards (http://www.genecards.org/), and the genes were used in this research when relevance score was more than 30.

Construction and analysis of component-action target network was based on Cytoscape software (version 3.7.2). Six compound and common target between COPD and Liquorice was imported to Cytoscape, after position adjustment network was finished.

The String database (https://string-db.org/) is one database containing known and predicted protein-protein interactions, in which a large number of protein-protein interactions were collected, involving a total of 9643763 proteins and 138838440 interactions, including data detected experimentally and predicted by bio-information methods. The common targets between disease and Liquorice were imported into the String database to define human species and obtain the protein interaction relationship. 
90 The results were saved in TSV format. The node1, node2 and combined score

91 information in the file was retained and imported into Cytoscape software to draw the 92 interaction network. The core of protein-protein interaction network was calculated in R software. Then GO enrichment analysis and KEGG pathway annotation analysis were finished in Rstudio with the p-value $<0.05$ as well.

III. Result

Figure 1 and Figure 2 showed the two and three dimension structure of formononetin, liquiritin, glycyrrhizin, glabridin, quercetin and isoliquiritigenin, respectively. Pharmacokinetic information was illustrated in Table 1. The number of H-bond donor/acceptor for formononetin, liquiritin, glycyrrhizin, glabridin, quercetin and isoliquiritigenin were $1 / 4,8 / 16,5 / 9,2 / 4,5 / 7$ and $6 / 9$, respectively. The oral bioavailability of formononetin, liquiritin, glycyrrhizin, glabridin, quercetin and isoliquiritigenin were $69.67,9.06,65.69,53.25,46.43$ and 8.61 , respectively.

There were 417 target molecule for COPD according to relevance score mentioned above and 64 target molecule for Liquorice (Figure 3). The intersection data set contains 20 molecular targets between COPD and liquorice. The information of the six active ingredientsand molecular targets of Licorice was introduced into Cytoscape to construct the network, as shown in Figure 4. There are a total of 58 nodes and 137 edges involved. The black type indicates the six ingredients of Licorice, blue ellipse represented the potential target. It can be seen from the Figure 4 that the same target could be corresponding to different active ingredients or the same active ingredient, which fully reflects the multi-component and multi-target action characteristics of Liquorice.

Figure 5 was the result after the process of String database. Color 'green' is the gene neighborhood, 'black' represents the co-expression, 'blue' is gene co-occurrence, 
117 'red' is the gene fusions. As shown in Figure 6, the link number of AKT1 was 39,

118 which is the highest level of interaction. Figure 7 presented the top ten key targets.

119 GO enrichment analysis is a finite acyclic graph that counts the number or 120 composition of proteins or genes at a functional level. The generatio of endopeptidase 121 activity and phosphatase were greater than the others. Nuclear receptor activity and 122 transcription factor activity, direct legend regulated sequence specific DNA binding were least (Figure 8, Table 2). The results of KEGG analysis are shown in Figure 9. The counts of proteoglycans in cancer, endocrine resistance, MAPK signaling pathway, EGFR tyrosine kinase inhibitor resistance, relaxin signaling pathway, Rap1 signaling pathway was $14,12,12,10,10$ and 10 , respectively.

COPD is a chronic bronchitis and/or emphysema characterized by airflow obstruction that could progress to pulmonary-heart disease and respiratory failure as a common chronic disease $[2,4,18]$. It has been formed a broad consensus that COPD is associated with abnormal inflammatory reactions with high morbidity and mortality[19]. Licorice has been internationally utilized for medicinal herb, while its mechanism of some main ingredients for COPD still kept unclear. The purpose of the present study was to investigate the effect of main ingredients on COPD according to network pharmacology.

In this study, it revealed that Akt1 is the common target between COPD and licorice. AKT1, also named as protein kinase B, is one of 3 closely related serine/threonine-protein kinases (AKT1, AKT2 and AKT3) called the AKT kinase,

140 and which regulates many processes including metabolism, proliferation, cell survival, 141 growth and angiogenesis[20-22]. It appeared as one key node in PI3K-AKT signaling, protects against acute lung injury[23]. Qu's experiment indicated that glycyrrhizic acid inhibited the production of inflammatory factors in LPS-induced ALI by 
regulating the PI3K/AKT/mTOR pathway related autophagy[24]. Vito Lorusso and Ilaria Marech summarized that isoliquiritigenin could suppress HIF-1 $\alpha$ level, VEGF expression and secretion, cell migration and to reduce the expression and secretion of MMP-9/-2 and these effects might be mediated through inhibition of p38, PI3K/Akt and NF- $\kappa \mathrm{B}$ signaling pathways[25].

As shown in Figure 8, MAPK1 was one of critical targets, which is an important transmitter of signals from the cell surface to the inside of the nucleus. The result of KEGG enrichment analysis also illustrated that licorice relieves COPD symptoms via MAPK signaling pathway. It has been reported that MAPK pathway is one of the common intersection pathways of signal transduction pathways including stress, inflammation, cell proliferation, differentiation, functional synchronization, transformation, apoptosis and so on. Previous studies demonstrated that MAPK signal pathway was involved in the inflammation reaction and oxidative stress[26, 27].

Some researchers also found that the ingredients of licorice has the function to mediate the expression of MAPK signaling pathway[28, 29].

The limitation of the present study was that this study was performed abstractly, in the future study, we will operate animal experiment to prove it with ethical approval.

\section{Conclusion}

MAPK signaling pathway could be the important key target of main ingredients of licorice on COPD. 
170 (https://pubchem.ncbi.nlm.nih.gov/). Pharmacokinetic information of these compound

171 was obtained from Traditional Chinese Medicine Systems Pharmacology (TCMSP).

172 The target molecule of the Liquorice ingredients were attained from public

173 database Swisstargetprediction (http://www.swisstargetprediction.ch/). The related

174 genes about COPD was collected from geneCards (http://www.genecards.org/).

175 VII. Consent to Publish

All author consent to publish this article in this article. 
[1]. Wedzicha JA, Seemungal TA. COPD exacerbations: defining their cause and prevention[J]. LANCET. 2007;370(9589):786-96.

[2]. Welte T, Vogelmeier C, Papi A. COPD: early diagnosis and treatment to slow disease progression[J]. INT J CLIN PRACT. 2015;69(3):336-49.

[3]. Agrawal R, Moghtader S, Ayyala U, Bandi V, Sharafkhaneh A. Update on management of stable chronic obstructive pulmonary disease[J]. J THORAC DIS. 2019;11(Suppl 14):S1800-9.

[4]. Qaseem A, Wilt TJ, Weinberger SE, Hanania NA, Criner G, van der Molen T, Marciniuk DD, Denberg T. Diagnosis and management of stable chronic obstructive pulmonary disease: a clinical practice guideline update from the American College of Physicians, American College of Chest Physicians, American Thoracic Society, and European Respiratory Society[J]. ANN INTERN MED. 2011;155(3):179-91.

[5]. Ntritsos G, Franek J, Belbasis L, Christou MA, Markozannes G, Altman P, Fogel R, Sayre T. Gender-specific estimates of COPD prevalence: a systematic review and meta-analysis[J]. Int J Chron Obstruct Pulmon Dis. 2018;13:1507-14.

[6]. Houghton AM. Mechanistic links between COPD and lung cancer[J]. NAT REV CANCER. 2013;13(4):233-45.

[7]. Rabe KF, Hurst JR, Suissa S. Cardiovascular disease and COPD: dangerous liaisons?[J]. Eur Respir Rev. 2018;27(149).

[8]. Pooler A, Beech R. Examining the relationship between anxiety and depression and exacerbations of COPD which result in hospital admission: a systematic review[J]. Int J Chron Obstruct Pulmon Dis. 2014;9:315-30.

212 [9]. Miravitlles M, Ribera A. Understanding the impact of symptoms on the burden of COPD[J]. Respir Res. 2017;18(1):67.

214 [10]. Zhu B, Wang Y, Ming J, Chen W, Zhang L. Disease burden of COPD in China: a systematic review[J]. Int J Chron Obstruct Pulmon Dis. 2018;13:1353-64.

[11]. Dastagir G, Rizvi MA. Review - Glycyrrhiza glabra L. (Liquorice)[J]. PAK J PHARM SCI.

218 [12]. Maria PG, Sara F, Mario F, Lorenza S. Biological Effects of Licochalcones[J]. Mini Rev Med 219 Chem. 2019;19(8):647-56.

220 [13]. Wang X, Zhang H, Chen L, Shan L, Fan G, Gao X. Liquorice, a unique "guide drug" of 221 traditional Chinese medicine: a review of its role in drug interactions[J]. J ETHNOPHARMACOL. 2013;150(3):781-90.

[14]. Ramalingam M, Kim H, Lee Y, Lee YI. Phytochemical and Pharmacological Role of Liquiritigenin and Isoliquiritigenin From Radix Glycyrrhizae in Human Health and Disease Models[J]. FRONT AGING NEUROSCI. 2018;10:348.

226 [15]. Yang R, Yuan BC, Ma YS, Zhou S, Liu Y. The anti-inflammatory activity of licorice, a widely used Chinese herb[J]. PHARM BIOL. 2017;55(1):5-18.

228 [16]. Pastorino G, Cornara L, Soares S, Rodrigues F, Oliveira M. Liquorice (Glycyrrhiza glabra): A 229 phytochemical and pharmacological review[J]. PHYTOTHER RES. 2018;32(12):2323-39.

230 [17]. Sun ZG, Zhao TT, Lu N, Yang YA, Zhu HL. Research Progress of Glycyrrhizic Acid on Antiviral 
Activity[J]. Mini Rev Med Chem. 2019;19(10):826-32.

[18]. Chen C, Liu X, Wang X, Qu W, Li W, Dong L. Effect of air pollution on hospitalization for acute exacerbation of chronic obstructive pulmonary disease, stroke, and myocardial infarction[J]. Environ Sci Pollut Res Int. 2020;27(3):3384-400.

[19]. Li MH, Fan LC, Mao B, Yang JW, Choi A, Cao WJ, Xu JF. Short-term Exposure to Ambient Fine Particulate Matter Increases Hospitalizations and Mortality in COPD: A Systematic Review and Meta-analysis[J]. CHEST. 2016;149(2):447-58.

[20]. Nicholson KM, Anderson NG. The protein kinase B/Akt signalling pathway in human malignancy[J]. CELL SIGNAL. 2002;14(5):381-95.

[21]. Hers I, Vincent EE, Tavare JM. Akt signalling in health and disease[J]. CELL SIGNAL. 2011;23(10):1515-27.

[22]. Heron-Milhavet L, Khouya N, Fernandez A, Lamb NJ. Akt1 and Akt2: differentiating the aktion[J]. HISTOL HISTOPATHOL. 2011;26(5):651-62.

[23]. Reddy NM, Potteti HR, Vegiraju S, Chen HJ, Tamatam CM, Reddy SP. PI3K-AKT Signaling via Nrf2 Protects against Hyperoxia-Induced Acute Lung Injury, but Promotes Inflammation Post-Injury Independent of Nrf2 in Mice[J]. PLOS ONE. 2015;10(6):e129676.

[24]. Qu L, Chen C, He W, Chen Y, Li Y, Wen Y, Zhou S, Jiang Y. Glycyrrhizic acid ameliorates LPS-induced acute lung injury by regulating autophagy through the PI3K/AKT/mTOR pathway[J]. AM J TRANSL RES. 2019;11(4):2042-55.

[25]. Lorusso V, Marech I. Novel plant-derived target drugs: a step forward from licorice?[J]. Expert Opin Ther Targets. 2013;17(4):333-5.

[26]. Guan R, Wang J, Li D, Li Z, Liu H, Ding M, Cai Z, Liang X. Hydrogen sulfide inhibits cigarette smoke-induced inflammation and injury in alveolar epithelial cells by suppressing PHD2/HIF-1alpha/MAPK signaling pathway[J]. INT IMMUNOPHARMACOL. 2020;81:105979.

[27]. Sun Y, Liu WZ, Liu T, Feng X, Yang N, Zhou HF. Signaling pathway of MAPK/ERK in cell proliferation, differentiation, migration, senescence and apoptosis[J]. J Recept Signal Transduct Res. 2015;35(6):600-4.

[28]. Frattaruolo L, Carullo G, Brindisi M, Mazzotta S, Bellissimo L, Rago V, Curcio R, Dolce V. Antioxidant and Anti-Inflammatory Activities of Flavanones from Glycyrrhiza glabra L. (licorice) Leaf Phytocomplexes: Identification of Licoflavanone as a Modulator of NF-kB/MAPK Pathway[J]. Antioxidants (Basel). 2019;8(6).

[29]. Liu W, Huang S, Li Y, Li Y, Li D, Wu P, Wang Q, Zheng X. Glycyrrhizic acid from licorice down-regulates inflammatory responses via blocking MAPK and PI3K/Akt-dependent NF-kappaB signalling pathways in TPA-induced skin inflammation[J]. MEDCHEMCOMM. 2018;9(9):1502-10. 
bioRxiv preprint doi: https://doi.org/10.1101/2021.08.29.458060; this version posted September 1, 2021. The copyright holder for this

preprint (which was not certified by peer review) is the author/funder, who has granted bioRxiv a license to display the preprint in perpetuity. It is made available under aCC-BY-NC-ND 4.0 International license.

Table 1 Pharmacokinetic information about six compounds

268

\begin{tabular}{cccccc}
\hline & Hdon & Hacc & OB $(\%)$ & Caco-2 & DL \\
\hline Formononetin & 1 & 4 & 69.67 & 0.78 & 0.21 \\
Liquiritin & 8 & 16 & 9.06 & -2.23 & 0.11 \\
Glycyrrhizin & 5 & 9 & 65.69 & -1.06 & 0.74 \\
Glabridin & 2 & 4 & 53.25 & 0.97 & 0.47 \\
Quercetin & 5 & 7 & 46.43 & 0.05 & 0.28 \\
Isoliquiritigenin & 6 & 9 & 8.61 & -1.36 & 0.6 \\
\hline
\end{tabular}

269

270 
bioRxiv preprint doi: https://doi.org/10.1101/2021.08.29.458060; this version posted September 1, 2021. The copyright holder for this preprint (which was not certified by peer review) is the author/funder, who has granted bioRxiv a license to display the preprint in perpetuity. It is made available under aCC-BY-NC-ND 4.0 International license.

271

272

Table $2 \mathrm{GO}$ enrichment analysis result

\begin{tabular}{cccc}
\hline ID & Description & pvalue & Count \\
\hline GO:0019902 & phosphatase binding & $2.12 \mathrm{E}-09$ & 9 \\
GO:0004713 & protein tyrosine kinase activity & $3.60 \mathrm{E}-09$ & 8 \\
GO:0019903 & protein phosphatase binding & $5.09 \mathrm{E}-09$ & 8 \\
GO:0004252 & serine-type endopeptidase activity & $1.46 \mathrm{E}-08$ & 8 \\
GO:0004714 & transmembrane receptor protein tyrosine kinase activity & $2.03 \mathrm{E}-08$ & 6 \\
GO:0008236 & serine-type peptidase activity & $3.98 \mathrm{E}-08$ & 8 \\
GO:0017171 & serine hydrolase activity & $4.72 \mathrm{E}-08$ & 8 \\
GO:0019199 & transmembrane receptor protein kinase activity & $8.87 \mathrm{E}-08$ & 6 \\
GO:0004175 & endopeptidase activity & $2.61 \mathrm{E}-07$ & 10 \\
GO:0004222 & metalloendopeptidase activity & $4.33 \mathrm{E}-07$ & 6 \\
\hline
\end{tabular}

273

274 
Figure 1 The two and three demonsion structure compounds (A:

formononetin; B: liquiritin; C: glycyrrhizin )

Figure 2 The two and three demonsion structure of conpounds

Figure 3 The target molecule of COPD and liquorice

Figure 4 The interaction network COPD, liquorice and molecular targets

Figure 5 The structure of protain-protain interaction network

Figure 6 PPI network link number

Figure 7 The top ten targets in the PPI network

Figure 8 The result of GO enrichment analysis

Figure 9 The result of KEGG enrichment analysis 
bioRxiv preprint doi: https://doi.org/10.1101/2021.08.29.458060; this version posted September 1, 2021. The copyright holder for this preprint (which was not certified by peer review) is the author/funder, who has granted bioRxiv a license to display the preprint in perpetuity. It is made available under aCC-BY-NC-ND 4.0 International license.
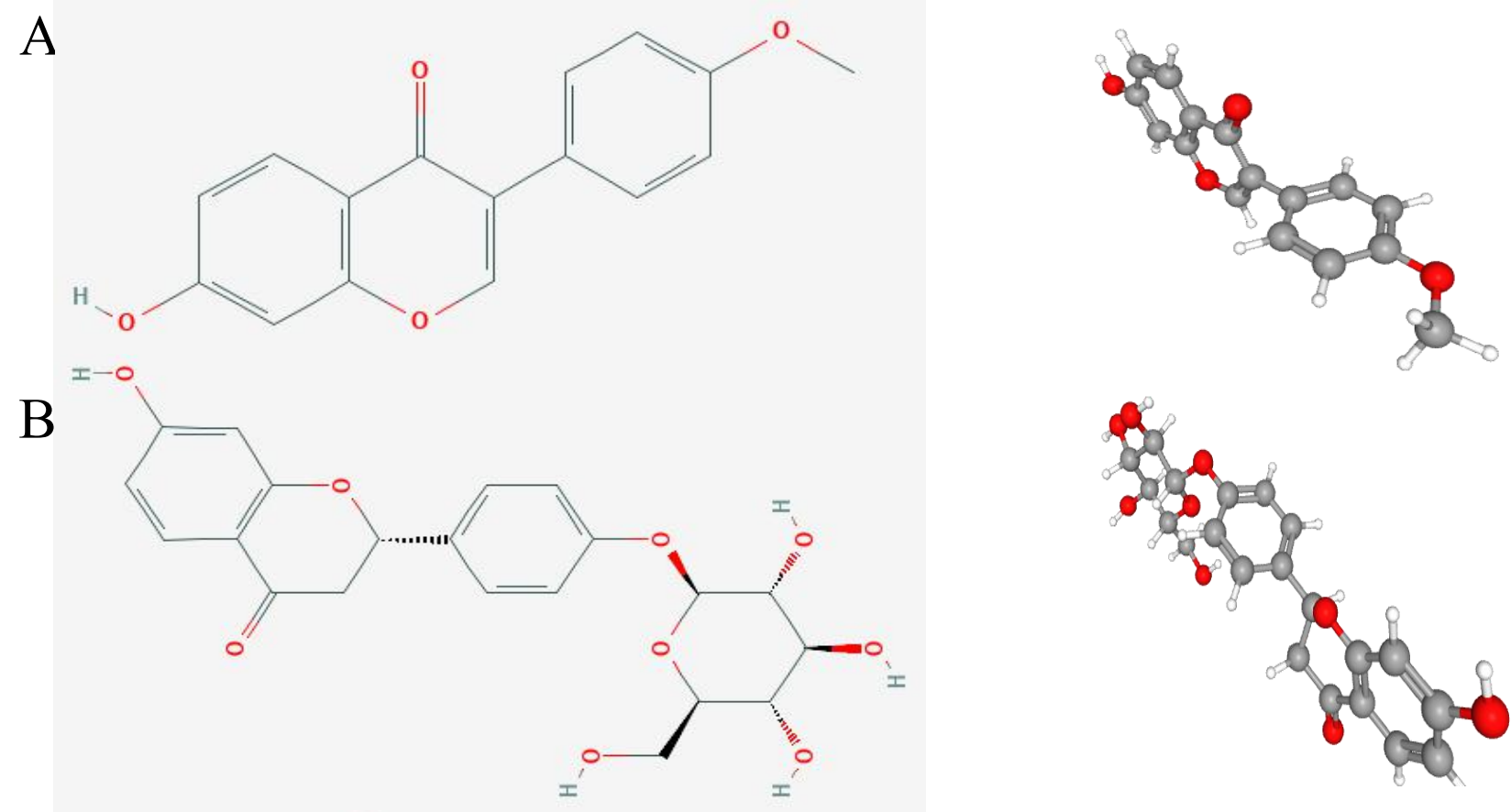

C

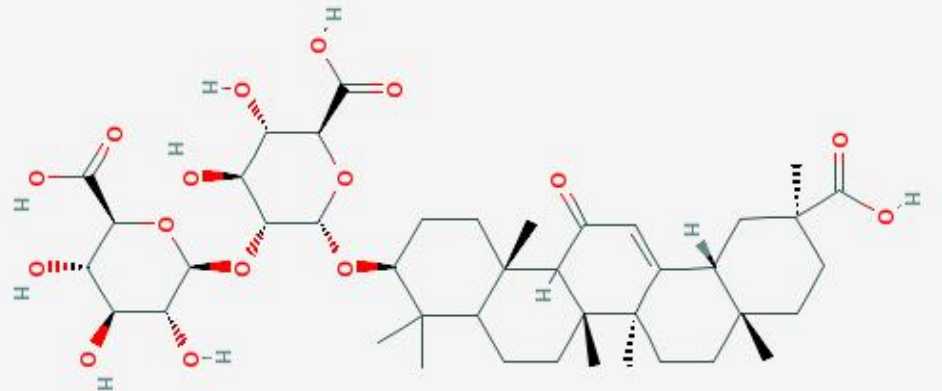

Figure 1 The two and three demonsion structure compounds (A: formononetin; B: liquiritin; C: glycyrrhizin ) 
bioRxiv preprint doi: https://doi org/10.1101/2021.08.29.458060; this version posted September 1, 2021. The copyright holder for this preprint (which was not certified by peer review) is the author/funder, who has granted bioRxiv a license to display the preprint in perpetuity. It is made available under aCC-BY-NC-ND 4.0 International license.

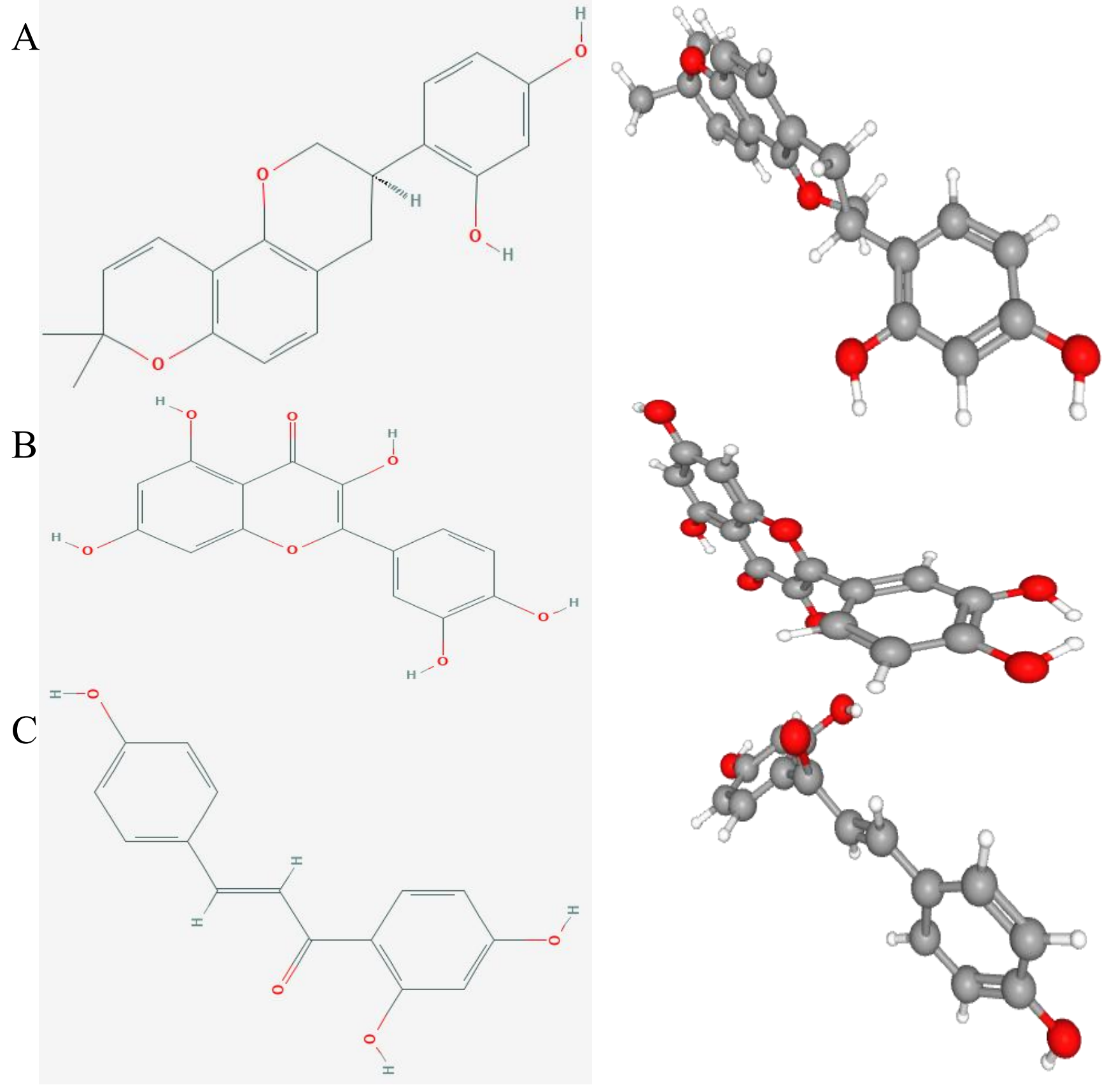

Figure 2 The two and three demonsion structure of conpounds

(A: glabridin; B: quercetin; C: isoliquiritigenin) 
bioRxiv preprint doi: https://doi.org/10.1101/2021.08.29.458060; this version posted September 1, 2021. The copyright holder for this preprint (which was not certified by peer review) is the author/funder, who has granted bioRxiv a license to display the preprint in perpetuity. It is made available under aCC-BY-NC-ND 4.0 International license.

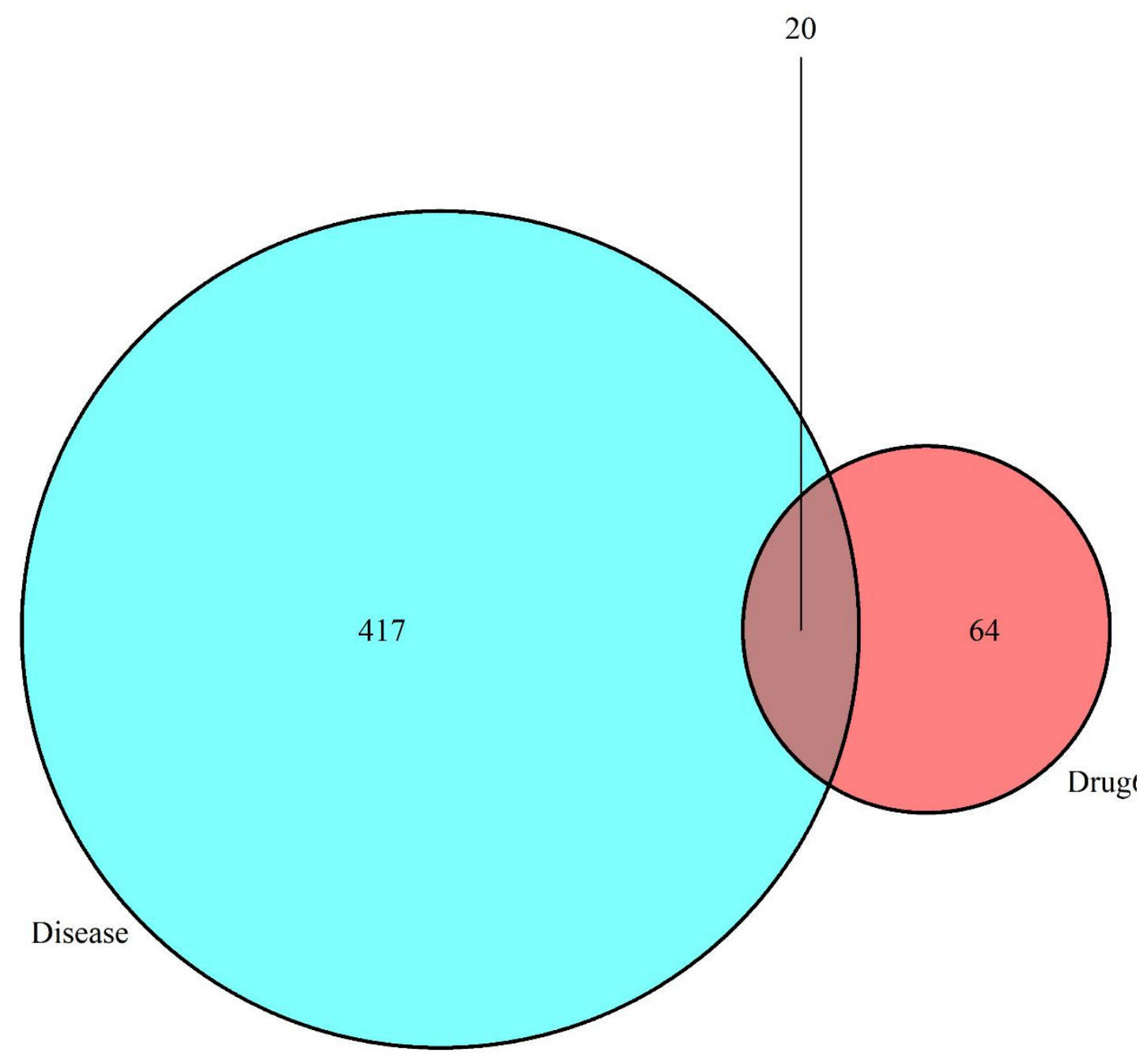

Figure 3 The target molecule of COPD and liquorice 
bioRxiv preprint doi: https://doi org/10.1101/2021.08 29 458060: this version posted September 1, 2021. The copyright holder for this preprint (which was not certified by peer review) is the author/funder, who has granted bioRxiv a license to display the preprint in perpetuity. It is made available under aCC-BY-NC-ND 4.0 International license.

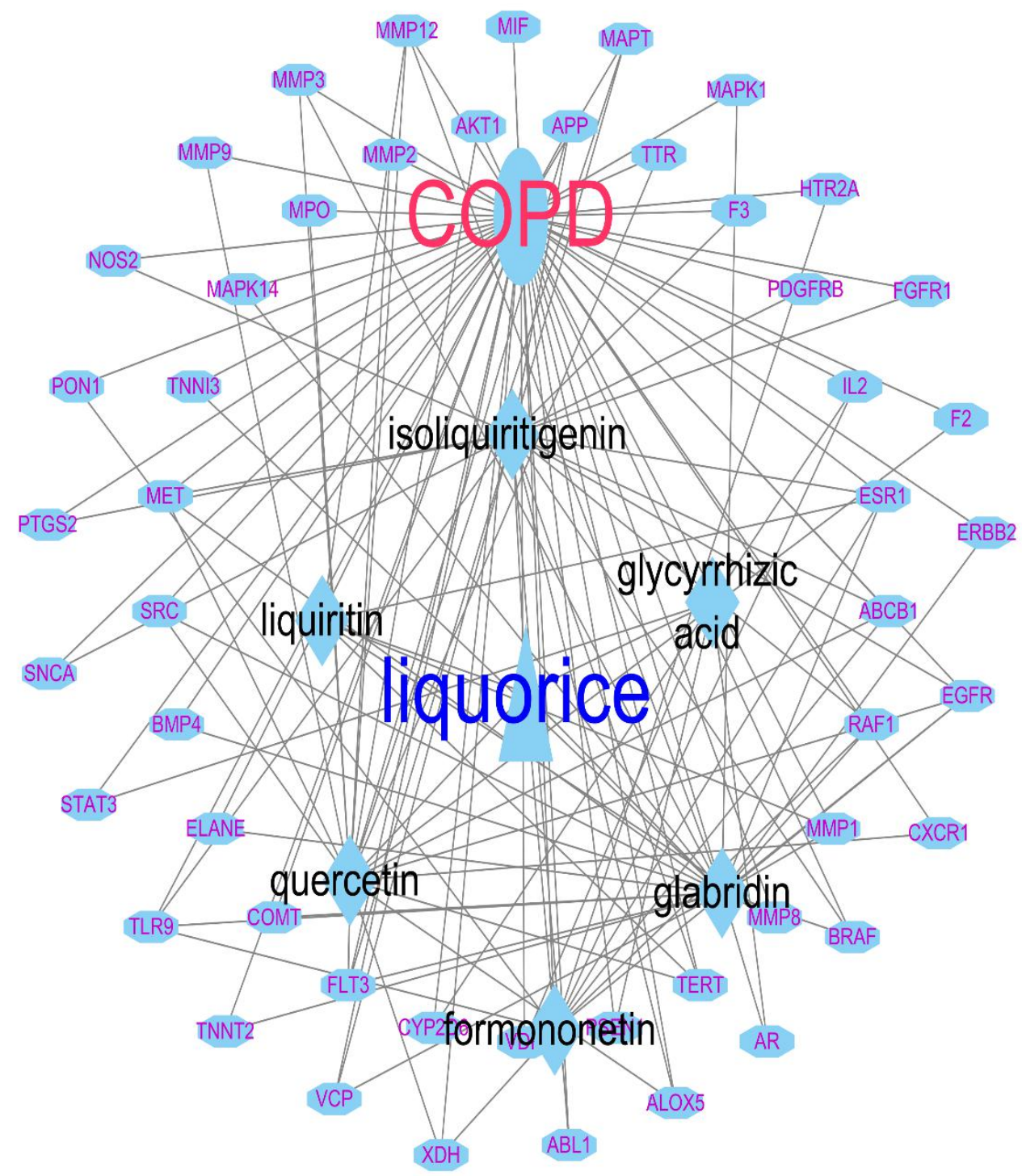

Figure 4 The interaction network COPD, liquorice and molecular targets 
bioRxiv preprint doi: https://doi.org/10.1101/2021.08 29 458060: this version posted September 1, 2021. The copyright holder for this

preprint (which was not certified by peer review) is the author/funder, who has granted bioRxiv a license to display the preprint in perpetuity. It is made available under aCC-BY-NC-ND 4.0 International license.

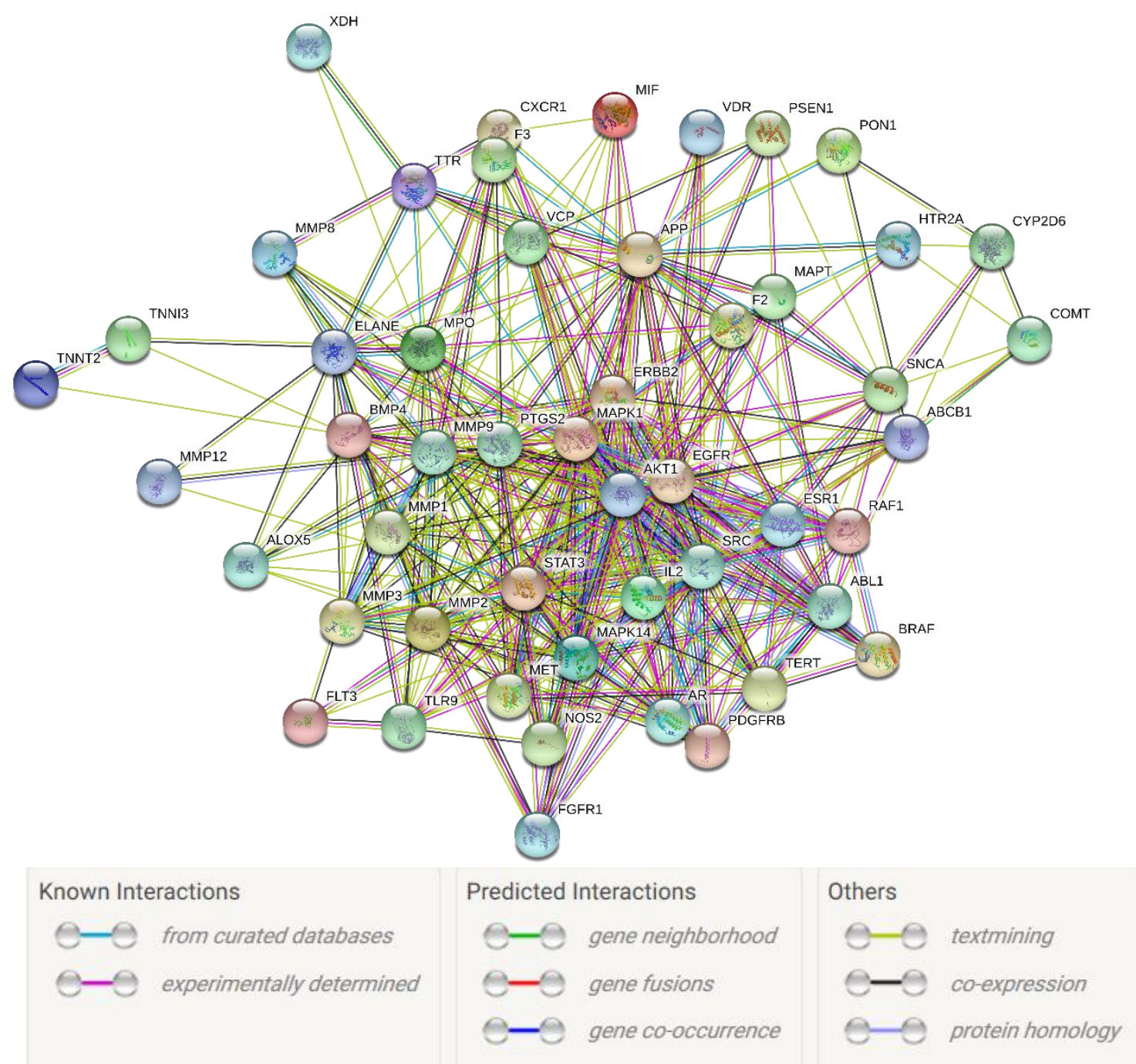

Figure 5 The structure of protain-protain interaction network 
bioRxiv preprint doi: https://doi org/10.1101/2021.08 29.458060. this version posted September 1, 2021. The copyright holder for this preprint (which was not certified by peer review) is the author/funder, who has granted bioRxiv a license to display the preprint in perpetuity. It is made available under aCC-BY-NC-ND 4.0 International license.

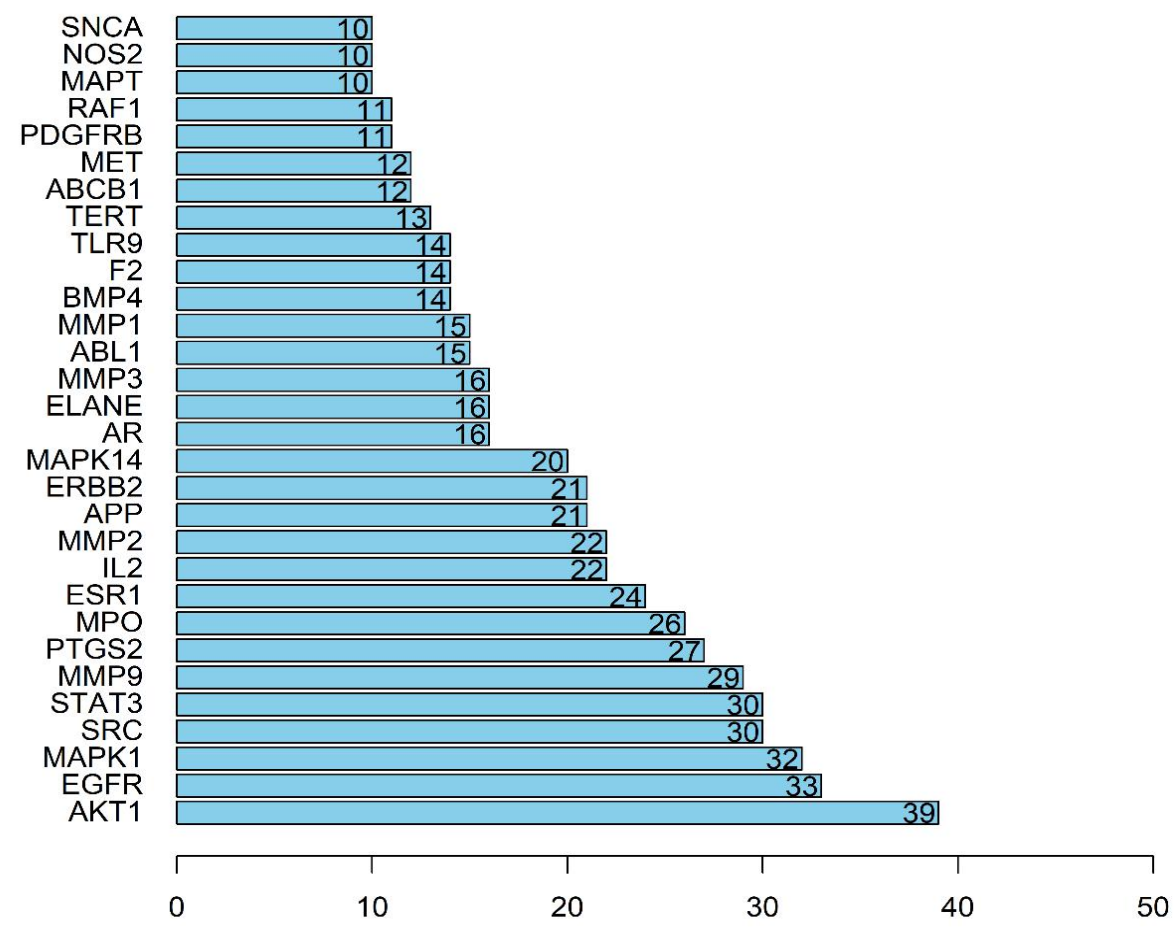

Figure 6 PPI network link number 
bioRxiv preprint doi: https://doi org/10.1101/2021 08 29.458060; this version posted September 1, 2021. The copyright holder for this preprint (which was not certified by peer review) is the author/funder, who has granted bioRxiv a license to display the preprint in perpetuity. It is made available under aCC-BY-NC-ND 4.0 International license.

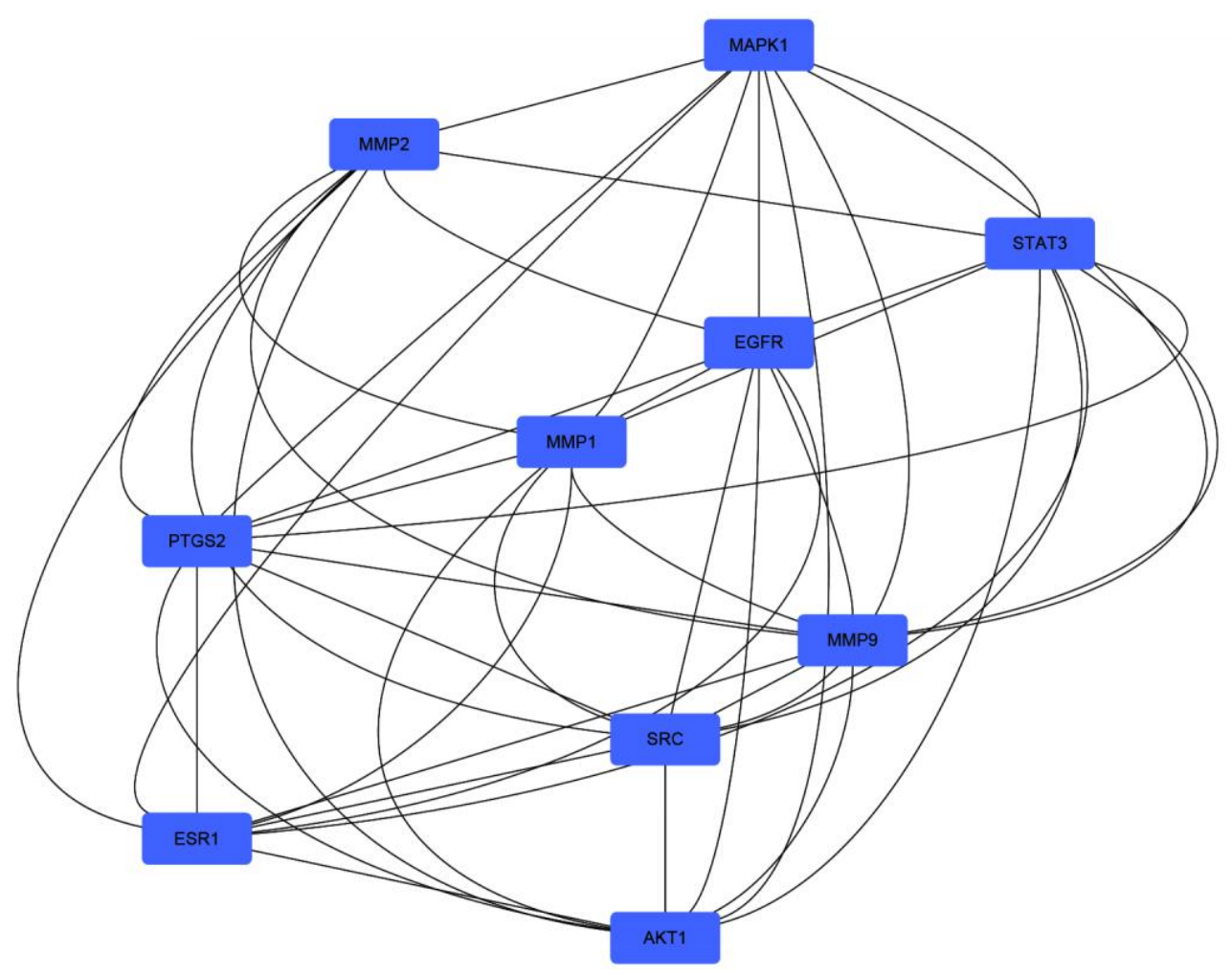

Figure 7 The top ten targets in the PPI network 
bioRxiv preprint doi: https://doi.org/10.1101/2021.08.29.458060; this version posted September 1, 2021. The copyright holder for this preprint (which was not certified by peer review) is the author/funder, who has granted bioRxiv a license to display the preprint in perpetuity. It is made available under aCC-BY-NC-ND 4.0 International license.

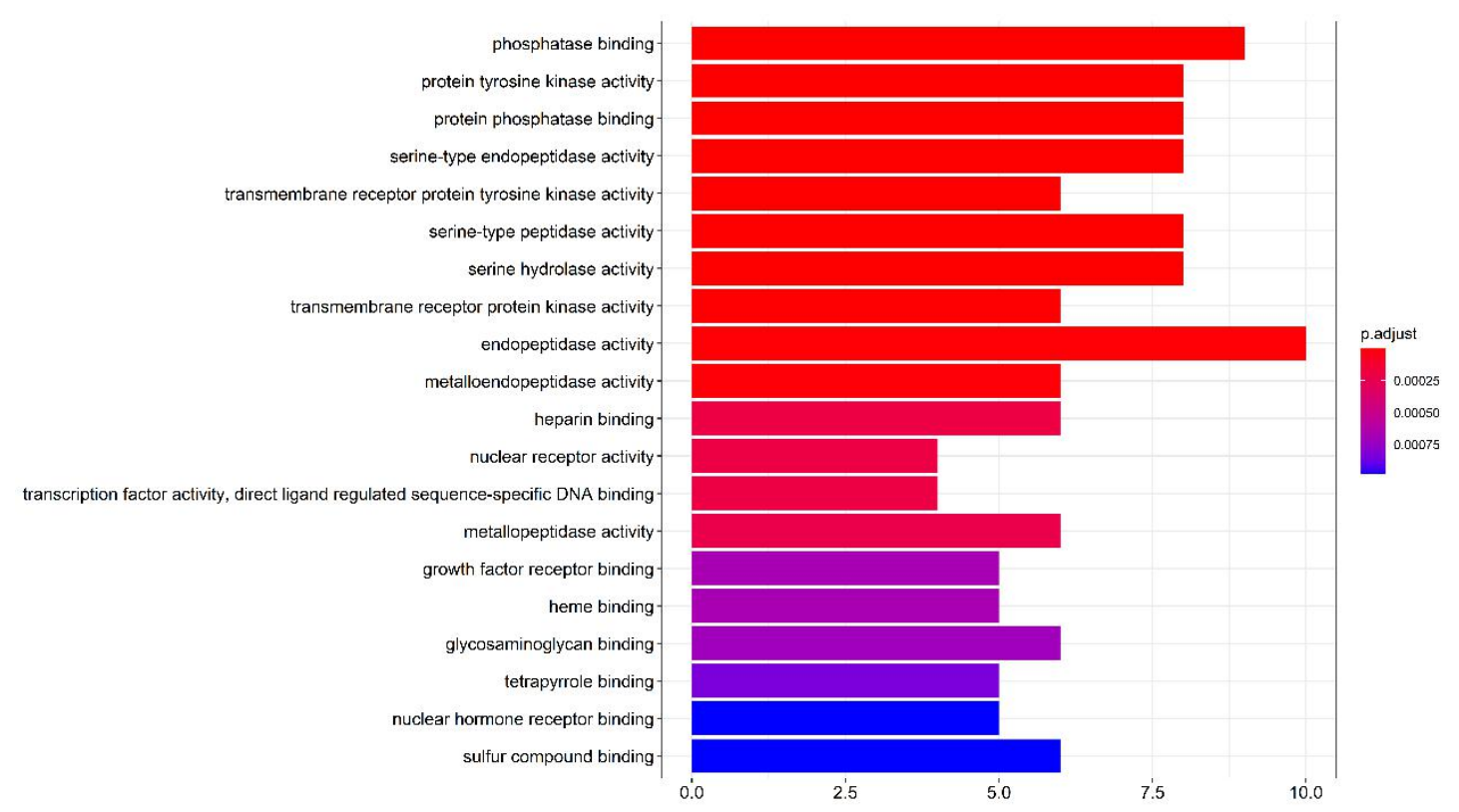

A

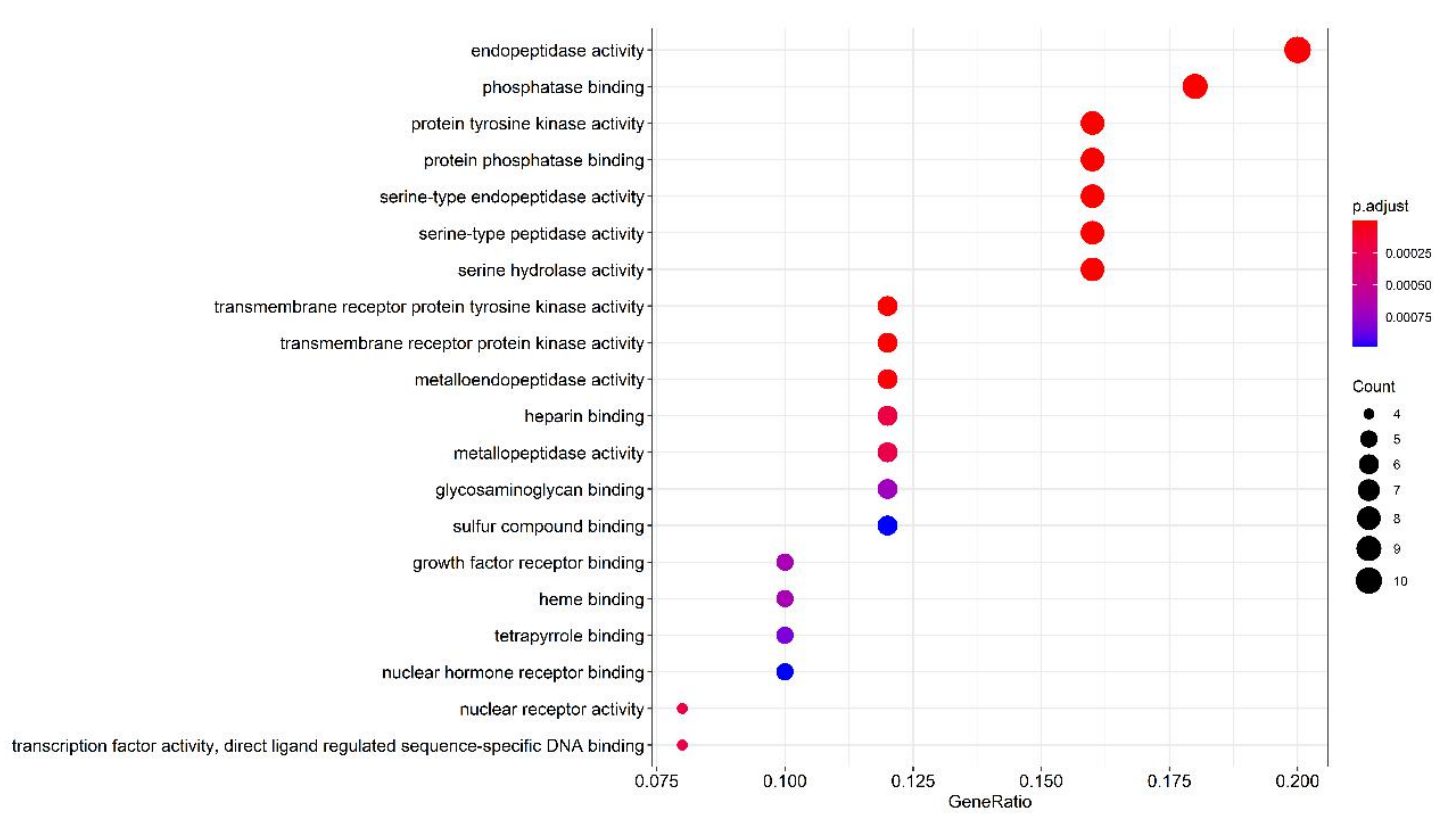

B

Figure $\quad 8 \quad$ The result of GO enrichment analysis 
bioRxiv preprint doi: https://doi.org/10.1101/2021.08.29.458060; this version posted September 1, 2021. The copyright holder for this preprint (which was not certified by peer review) is the author/funder, who has granted bioRxiv a license to display the preprint in perpetuity. It is made available under aCC-BY-NC-ND 4.0 International license.

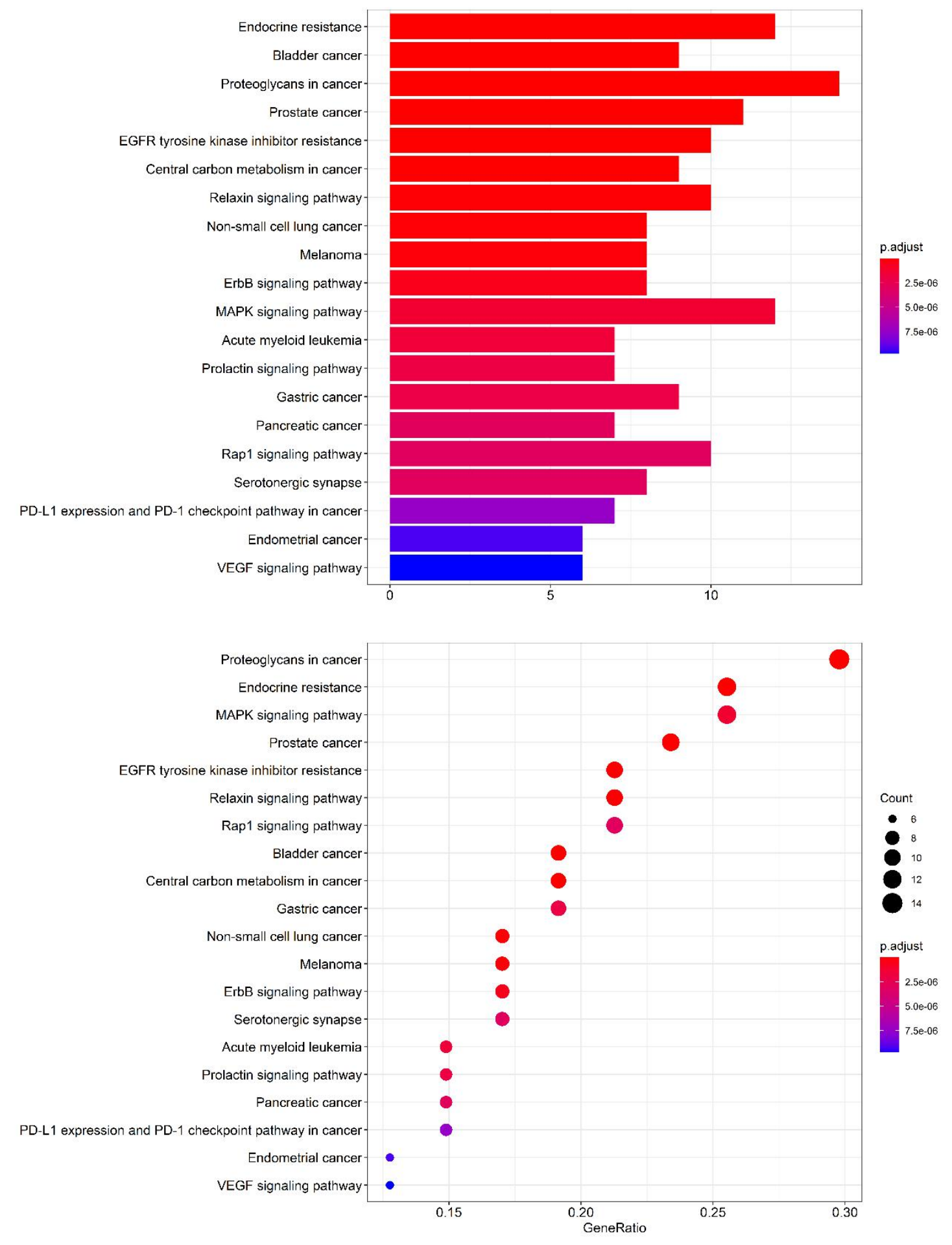

Figure 9 The result of KEGG enrichment analysis 